\title{
EFEKTIFITAS PENANAMAN TANAMAN SERAI WANGI (Cymbopogon nardus) TERHADAP INDIKATOR MAYA INDEX DBD DI KABUPATEN PRINGSEWU, LAMPUNG
}

\author{
Achmad Farich*, Agung Aji Perdana* \\ Email : farichrich@malahayati.ac.id
}

\begin{abstract}
ABSTRAK
Kejadian demam berdarah meningkat secara drastis di seluruh dunia, sebanyak 390 juta orang terinfeksi dengue per tahun. Kabupaten Pringsewu mengalami peningkatan kasus DBD pada tahun 2017 dibandingkan tahun 2015 dengan jumlah kasus 680 kasus, 3 diantaranya meninggal dunia. Dikenal ada banyak tanaman yang bisa menjadi pengusir nyamuk seperti tanaman serai. Penelitian ini bertujuan untuk mengetahui efektifitas tanaman serai wangi terhadap indikator Maya Index (MI) di Desa Wonodadi Kabupaten Pringsewu. Jenis penelitian adalah studi kuantitatif dengan desain pretest-postest nonequivalent group design. Indikator BRI dan HRI sebelum dan sesudah intervensi masuk dalam kategori tinggi di Desa Wonodadi dan Desa Rejosari. Indikator Maya index sesudah dilakukan intervensi di Desa Wonodadi mengalami kecenderungan menurun (33,3\%) dibandingkan Desa Rejosari yang mengalami kecenderungan meningkat $(34,72 \%)$. Maya index digunakan untuk mengidentifikasi sebuah lingkungan beresko tinggi sebagai tempat perkembangbiakan nyamuk Aedes aegypti atau tidak. Peningkatan kegiatan PSN diperlukan untuk menekan angka kasus DBD dan perlu adanya sebuah kebijakan daerah yaitu penanaman sereh untuk mengurangi resiko tempat perkembangbiakan nyamuk Aedes aegypti.
\end{abstract}

Kata Kunci : Maya index, Controllable Sites, Breeding Risk Index

\section{ABSTRACT}

The incidence of dengue fever has increased dramatically throughout the world, as many as 390 million people are infected with dengue per year. Pringsewu District experienced an increase in dengue cases in 2017 compared to 2015 with a total of 680 cases, 3 of which died. It is known that there are many plants that can become mosquito repellents such as lemongrass plants. This study aims to determine the effectiveness of citronella plants against the Maya Index (MI) indicator in Wonodadi Village, Pringsewu Regency. This type of research is a quantitative study with a pretest-posttest nonequivalent group design. BRI and HRI indicators before and after the intervention are in the high category in Wonodadi Village and Rejosari Village. Maya index indicator after intervention in Wonodadi Village experienced a downward trend $(33.3 \%)$ compared to Rejosari Village which experienced an upward trend (34.72\%). Maya index is used to identify a high-risk environment as a breeding ground for Aedes aegypti mosquitoes or not. The increase in PSN activities is needed to reduce the number of dengue cases and the need for a regional policy namely the planting of lemongrass to reduce the risk of Aedes aegypti mosquito breeding sites.

Keywords : Maya index, Controllable Sites, Breeding Risk Index

\section{PENDAHULUAN}

Demam berdarah dengue (DBD) adalah suatu penyakit infeksi yang disebabkan oleh virus dengue. Virus ini berasal dari genus Flavivirus famili Flaviridae yang vektornya adalah nyamuk Aedes aegypti dan Aedes albopictus. Virus dengue terdiri dari 4 serotive yaitu virus DEN-1, DEN-2, DEN 3, dan DEN- 4. Virus ini menyebabkan kesakitan dan kematian di negaranegara tropis dan sub tropis termasuk di Indonesia (CDC, 2014; WHO, 2016)

*. Fakultas Kesehatan Masyarakat Universitas Malahayati 
Kejadian demam berdarah meningkat secara drastis di seluruh dunia dalam beberapa dekade terakhir, sebanyak 390 juta orang terinfeksi dengue per tahun (Bhatt et al., 2013). Jumlah kasus di Amerika, Asia Tenggara dan Pasifik Barat melebihi 1,2 juta pada tahun 2008 dan lebih dari 3,2 juta pada tahun 2015. Pada tahun 2015, 2,35 juta kasus demam berdarah dilaporkan terjadi di Amerika, dimana 10.200 kasus didiagnosis sebagai demam berdarah berat yang menyebabkan 1.181 kematian (WHO, 2016).

Penyakit ini juga telah dilaporkan dari beberapa negara Afrika Utara, yitu Mesir, Mali dan Sudan. Kemudian negara di Amerika, termasuk Amerika Serikat. Kasus penyakit ini juga telah dilaporkan dari negara Asia salah satunya adalah Indonesia (Leta et al., 2018).

Pada tahun 2015 jumlah penderita DBD di Indonesia yang dilaporkan sebanyak 129.650 kasus dengan jumlah kematian sebanyak 1.071 orang (IR/Angka kesakitan= 50,75 per 100.000 penduduk dan CFR/angka kematian $=0,83 \%$ ). Dibandingkan tahun 2014 dengan kasus sebanyak 100.347 serta IR 39,80 terjadi peningkatan kasus pada tahun 2015 (Kemenkes, 2016). Pada tahun 2016 jumlah penderita DBD yang dilaporkan sebanyak 201.885 kasus dengan jumlah kematian sebesar 1.585 orang (IR/Angka kesakitan $=77,96$ per 100.000 penduduk dan CFR/angka kematian $=0,79 \%$ ) (Kemenkes, 2017).

Peningkatan kasus DBD juga terjadi di Provinsi Lampung di tahun 2016 dibandingkan tahun 2009, dengan angka Incidence rate (IR)tahun 2016 sebesar 74,86 per 100.000 penduduk dan CFR/angka kematian=0,42 (Dinkes Provinsi Lampung, 2016). Berdasarkan profil kesehatan Provinsi Lampung Kabupaten Pringsewu, Tulang Bawang Barat, Metro merupakan kabupaten dengan angka Incidence rate (IR) tertinggi. Kurangnya partisipasi masyarakat dalam kegiatan PSN (Pemberantasan Sarang Nyamuk) merupakan salah satu faktor yang menyebabkan penyebaran virus DBD semakin mudah dan luas (Dinkes Provinsi Lampung, 2016).
Kabupaten Pringsewu mengalami peningkatan kasus DBD pada tahun 2017 di bandingkan tahun 2015. Tercatat jumlah kasus di Kabupaten Pringsewu sebanyak 481 kasus, 4 diantaranya meninggal dunia. Pada tahun 2016 tercatat sebanyak 1022 kasus, 5 diantaranya meninggal dunia. Pada tahun 2017 untuk bulan Januari sampai November telah tercatat sebanyak 680 kasus, 3 diantaranya meninggal dunia (Dinkes Kabupaten Pringsewu, 2016).

Penelitian mengenai DBD telah banyak dilakukan selama ini adalah penelitian mengenai faktor risiko terjadinya DBD pada tingkat individu dan lingkungan (Dom, Ahmad, Ishak, \& Ismail, 2013; Kajeguka et al., 2017; Pang, Hsu, Yeo, Leo, \& Lye, 2017). Selain itu, berbagai hasil kajian yang menggali faktor kependudukan berupa, pengetahuan, sikap dan praktek yang mempengaruhi DBD juga telah banyak dilakukan, diantaranya oleh (Budiman, 2016; Istiqomah, BM, \& Husodo, 2017; Rulen, Siregar, \& Nazriati, 2017; Kamal dan Dharmadi,2017; Sayavong, Chompikul, Wongsawass, \& Rattanapan, 2015; Bota, Ahmed, Jamali, \& Aziz, 2014; Ho, Huang, Wang, Hsu, \& Liu, 2013;Ibrahim, Al-Bar, Kordey, \& AlFakeeh, 2009) yang menyimpulkan faktor-faktor yang menunjukkan adanya hubungan yang signifikan dengan kejadian DBD, antara lain : 1) tingkat pengetahuan tentang tanda atau gejala, 2) cara penularan dan pencegahan DBD, 3) kebiasaan tidur siang, 4) kebiasaan menggantung pakaian, 5) kebiasaan membersihkan tempat penampungan air, 6) kebiasaan membersihkan halaman di sekitar rumah, 7) tempat penampungan air di dalam atau di luar rumah yang terbuka, dan 8 ) tempat penampungan air di dalam atau di luar rumah yang positif jentik.

Keterlibatan masyarakat dalam memberantas DBD merupakan kontribusi yang penting dan perlu dibina agar secara sadar hidup dalam lingkungan yang bersih sehingga mencegah perkembangbiakan vektor Demam Berdarah Dengue. Oleh karena itu, intervensi lingkungan dan perilaku menjadi kunci pokok dalam penanggulangan penyakit DBD. Semua 
program yang dilaksanakan selama ini banyak didominasi oleh peran dari tenaga kesehatan, sedangkan partisipasi masyarakat tidak terbangun. Dibutuhkan juga suatu model yang dapat meningkatkan perilaku pencegahan Demam Berdarah Dengue dengan kegiatan ekonomi produktif, melalui pengembangan tanaman pengusir nyamuk yang memiliki nilai ekonomi sehingga merangsang masyarakat untuk terus menerus melakukan kegiatan pencegahan karena menjadi kebutuhan untuk mendapatkan penghasilan secara ekonomi.

Dikenal ada banyak tanaman yang bisa menjadi pengusir nyamuk, dari berbagai jenis ada yang memiliki nilai ekonomis yang cukup tinggi sehingga bisa juga dimanfaatkan untuk meningkatkan pendapatan keluarga sekaligus akan merangsang masyarakat untuk melestarikan dan mengembangakan tanaman tersebut yang berimplikasi pada keberlangsungan program pencegahan DBD. Tanaman pengusir nyamuk sebagian ada yang sudah diketahui masyarakat seperti tanaman serei hanya mereka tidak tahu bahwa tanaman tersebut bisa menjadi sumber penghasilan yang menjanjikan jika dikelola dengan baik dan pada tahap awal difasilitasi untuk pemasarannya.

Berdasarkan uraian di atas, maka penulis tertarik untuk melakukan penelitian tentang efektifitas tanaman serai wangi (Cymbopogon nardus) terhadap indikator maya index DBD di Kabupaten Pringsewu

\section{METODE PENELITIAN}

Penelitian ini menggunakan desain pre dan post test design. Populasi dalam penelitian ini adalah anggota keluarga yang pernah memiliki riwayat rekam medis dan didiagnosis secara klinis dan/atau laboratoris sebagai penderita demam berdarah dengue dalam 1 tahun terakhir dan berdomisili di Desa Wonodadi dan Desa Rejosari. Sampel dalam penelitian ini diambil menggunakan teknik pengambilan sampel proporsional stratified random samping. Berdasarkan perhitungan sampel menggunakan uji hipotesis beda 2 proporsi, diperoleh jumlah sampel sebanyak 120 responden. Pengumpulan data dilakukan dengan observasi langsung di lapangan. Setiap rumah yang masuk dalam sampel di ukur indikator entomolognya dengan menggunakan lembar observasi survey jentik aedes aegypti. Analisis data yang dilakukan yaitu analisis univariat.

Cara kerja pengukuran indikator entomologi :

Pengukuran indikator entomologi dilakukan dengan cara mengobservasi semua tempat potensial perindukan nyamuk aedes aegypti sebelum dan sesudah penanaman sereh wangi. Observasi dilakukan dengan menggunakan formulir ceklis pengamatan jentik di dalam dan di luar rumah dengan cara sebagai berikut

1. Semua tempat atau bejana yang dapat menjadi tempat perkembangbiakan nyamuk Aedes aegypti diperiksa (dengan mata telanjang) untuk mengetahui ada tidaknya jentik.

2. Untuk memeriksa tempat penampungan air yang berukuran besar, seperti: bak mandi, tempayan, drum dan bak penampung air lainnya. Jika pada pandangan (penglihatan) pertama tidak menemukan jentik, tunggu kira-kira $1 / 2$ - 1 menit untuk memastikan bahwa benar tidak ada jentik.

3. Untuk memeriksa tempat-tempat perkembangbiakan yang kecil, seperti: vas bunga/pot tanaman, air/botol yang airnya keruh, airnya perlu dipindahkan ke tempat lain.

4. Untuk memeriksa jentik di tempat yang agak gelap, atau airnya keruh, biasanya digunakan senter.

Cara kerja Penanaman Sereh Wangi :

1. Persiapan lahan : mencangkul lahan,membuat guludan selebar 120 $\mathrm{cm}$, penutupan bedeng guludan menggunakan mulsa plastik dua sisi, melubangi mulsa plastik dengan diameter lubang $\pm 15 \mathrm{~cm}$

2. Penanaman : bibit yang ditanam berupa stek anakan yang didapat dengan cara memecah rumpun yang berukuran besar, dipotong daunnya hingga sekitar 3-5 $\mathrm{cm}$ dari pelepah daun 
3. Pemupukan : pemupukan sekitar 150 - $300 \mathrm{~kg}$ urea, $25-50$ kg TSP, 125 - $250 \mathrm{~kg} \mathrm{KCl}$ per hektar yang diaplikasikan sekali setahun.

\section{HASIL}

Tempat penampungan air yang diperiksa sebelum intervensi sebanyak 3307 kontainer, yaitu pada Desa Wonodadi 996 buah dan Desa Rejosari 2311 buah. Proporsi controllable sites (CS) pada Desa Rejosari lebih banyak, yakni 1243 buah dibandingkan dengan Desa Wonodadi 607 buah. Proporsi Disposable Sites (DS) pada Desa Rejosari lebih banyak, yakni 1038 buah dibandingkan dengan Desa Wonodadi 368 buah.

Di Desa Wonodadi (intervensi) Jenis kontainer controllable sites (CS) yang positif jentik paling banyak, yakni bak mandi (36 buah) dan ember (19 buah). Jenis kontainer Disposable Sites (DS) yang positif jentik paling banyak, yakni ember bekas (12 buah) drum bekas (10 buah) dan ban bekas ( 9 buah). Jenis kontainer UnderControllable sites (US) yang positif jentik paling banyak, yakni kolam ikan (57 buah)

Di Desa Rejosari (kontrol) Jenis kontainer controllable sites (CS) yang positif jentik paling banyak, yakni bak mandi (25 buah) dan ember (18 buah). Jenis kontainer Disposable Sites (DS) yang positif jentik paling banyak, yakni ember bekas ( 6 buah), drum bekas ( 5 buah) dan ban bekas (5 buah). Jenis kontainer UnderControllable sites (US) yang positif jentik paling banyak, yakni kolam ikan (1 buah).

Tabel 1

Jumlah Tempat Penampungan Air (TPA) Sebelum dan Sesudah Intervensi Pada Kelompok Intervensi (Desa Wonodadi) dan Kelompok Kontrol (Desa Rejosari) Tahun 2019

\begin{tabular}{|c|c|c|c|c|c|c|c|c|}
\hline \multirow{3}{*}{ Jenis TPA } & \multicolumn{4}{|c|}{ Desa Wonodadi } & \multicolumn{4}{|c|}{ Desa Rejosari } \\
\hline & \multicolumn{2}{|c|}{ Sebelum } & \multicolumn{2}{|c|}{ Sesudah } & \multicolumn{2}{|c|}{ Sebelum } & \multicolumn{2}{|c|}{ Sesudah } \\
\hline & $\mathbf{n}$ & + & $\mathbf{n}$ & + & $\mathbf{n}$ & + & $\mathbf{n}$ & + \\
\hline \multicolumn{9}{|l|}{ Controllable Sites } \\
\hline Talang air & 5 & 1 & 13 & 0 & 100 & 1 & 101 & 0 \\
\hline Ember & 250 & 19 & 272 & 11 & 341 & 18 & 410 & 0 \\
\hline Pot bunga & 74 & 0 & 40 & 0 & 283 & 9 & 233 & 0 \\
\hline Drum & 42 & 5 & 39 & 3 & 42 & 1 & 41 & 0 \\
\hline Sumur & 28 & 3 & 23 & 0 & 73 & 3 & 97 & 1 \\
\hline Bak mandi & 114 & 36 & 91 & 11 & 109 & 25 & 118 & 4 \\
\hline Dispenser & 26 & 3 & 20 & 0 & 22 & 0 & 27 & 1 \\
\hline Tempat minum burung & 5 & 0 & 1 & 0 & 95 & 4 & 114 & 3 \\
\hline Jerigen & 5 & 0 & 3 & 0 & 162 & 1 & 140 & 0 \\
\hline Gentong & 18 & 3 & 12 & 1 & 16 & 0 & 22 & 0 \\
\hline Lain-lain & 40 & 7 & 12 & 0 & 0 & 0 & 7 & 0 \\
\hline \multicolumn{9}{|l|}{ Disposable Sites } \\
\hline Kaleng bekas & 55 & 1 & 2 & 0 & 236 & 1 & 165 & 0 \\
\hline Botol bekas & 67 & 1 & 13 & 0 & 234 & 2 & 169 & 0 \\
\hline Ban bekas & 23 & 9 & 0 & 0 & 43 & 5 & 46 & 1 \\
\hline Ember bekas & 84 & 12 & 23 & 5 & 112 & 6 & 113 & 0 \\
\hline Toples bekas & 18 & 1 & 2 & 0 & 288 & 1 & 168 & 0 \\
\hline Gelas bekas & 67 & 0 & 0 & 0 & 84 & 2 & 37 & 0 \\
\hline Drum bekas & 23 & 10 & 11 & 4 & 17 & 5 & 16 & 0 \\
\hline Lain-lain & 31 & 7 & 0 & 0 & 24 & 0 & 145 & 0 \\
\hline \multicolumn{9}{|l|}{ UnderControllable sites } \\
\hline Kolam ikan & 17 & 7 & 7 & 2 & 21 & 1 & 12 & 0 \\
\hline Akuarium & 4 & 0 & 1 & 0 & 9 & 0 & 10 & 9 \\
\hline Total & 996 & 125 & 585 & 37 & 2311 & 85 & 2191 & 19 \\
\hline
\end{tabular}

Berdasarkan Tabel 2. terlihat bahwa BRI dengan kategori tinggi sebelum intervensi di Desa Wonodadi dan pengumpulan data pertama di Desa Rejosari paling tinggi terdapat di Desa Wonodadi sebanyak 50,8\%. Setelah 
dilakukan intervensi di Desa Wonodadi dan pengumpulan data kedua di Desa Rejosari terlihat bahwa BRI paling tinggi terdapat di Desa Rejosari sebanyak 78,3\%. Kategori HRI tinggi sebelum intervensi di Desa Wonodadi dan pengumpulan data pertama di Desa Rejosari paling tinggi terdapat di Desa Rejosari sebanyak 40\%. Setelah dilakukan intervensi HRI paling tinggi terdapat di Desa Rejosari sebanyak $33,3 \%$.

Tabel 2

Distribusi Frekuensi Kontainer Berdasarkan BRI dan HRI Sebelum dan Sesudah Intervensi Pada Kelompok Intervensi (Desa Wonodadi) dan Kelompok Kontrol (Desa Rejosari) Tahun 2019

\begin{tabular}{|c|c|c|c|c|c|c|c|c|}
\hline \multirow[b]{3}{*}{ Kategori } & \multicolumn{2}{|c|}{$\begin{array}{c}\text { Breeding Risk } \\
\text { Index (BRI) } \\
\end{array}$} & \multicolumn{2}{|c|}{$\begin{array}{c}\text { Hygine Risk Index } \\
\text { (HRI) }\end{array}$} & \multicolumn{2}{|c|}{$\begin{array}{l}\text { Breeding Risk } \\
\text { Index (BRI) }\end{array}$} & \multicolumn{2}{|c|}{$\begin{array}{c}\text { Hygine Risk Index } \\
\text { (HRI) }\end{array}$} \\
\hline & \multicolumn{4}{|c|}{ Desa Wonodadi } & \multicolumn{4}{|c|}{ Desa Rejosari } \\
\hline & Sebelum & Sesudah & Sebelum & Sesudah & $\begin{array}{l}\text { Pengum } \\
\text { pulan } \\
\text { Data } \\
\text { Pertama }\end{array}$ & $\begin{array}{c}\text { Pengum } \\
\text { pulan } \\
\text { Data } \\
\text { Kedua } \\
\end{array}$ & $\begin{array}{l}\text { Pengum } \\
\text { pulan } \\
\text { Data } \\
\text { Pertama }\end{array}$ & $\begin{array}{c}\text { Pengum } \\
\text { pulan } \\
\text { Data } \\
\text { Kedua } \\
\end{array}$ \\
\hline Rendah & $\begin{array}{c}37 \\
(30.8 \%)\end{array}$ & $\begin{array}{c}29 \\
(24.2 \%)\end{array}$ & $\begin{array}{c}63 \\
(52.5 \%)\end{array}$ & $\begin{array}{c}96 \\
(80 \%)\end{array}$ & $\begin{array}{c}38 \\
(31.7 \%)\end{array}$ & $\begin{array}{c}8 \\
(6.7 \%)\end{array}$ & $\begin{array}{c}39 \\
(32.5 \%)\end{array}$ & $\begin{array}{c}40 \\
(33.3 \%)\end{array}$ \\
\hline Sedang & $\begin{array}{c}22 \\
(18.3 \%)\end{array}$ & $\begin{array}{c}52 \\
(43.3 \%)\end{array}$ & $\begin{array}{c}15 \\
(12.5 \%)\end{array}$ & $\begin{array}{c}14 \\
(11.7 \%)\end{array}$ & $\begin{array}{c}49 \\
(40.8 \%)\end{array}$ & $\begin{array}{c}18 \\
(15 \%)\end{array}$ & $\begin{array}{c}33 \\
(27.5 \%\end{array}$ & $\begin{array}{c}40 \\
(33.3 \%)\end{array}$ \\
\hline Tinggi & $\begin{array}{c}61 \\
(50.8 \%)\end{array}$ & $\begin{array}{c}39 \\
(32.5 \%)\end{array}$ & $\begin{array}{c}42 \\
(35 \%)\end{array}$ & $\begin{array}{c}10 \\
(8.3 \%)\end{array}$ & $\begin{array}{c}33 \\
(27.5 \%)\end{array}$ & $\begin{array}{c}94 \\
(78.3 \%)\end{array}$ & $\begin{array}{c}48 \\
(40 \%)\end{array}$ & $\begin{array}{c}40 \\
(33.3 \%)\end{array}$ \\
\hline Total & 120 & 120 & 120 & 120 & 120 & 120 & 120 & 120 \\
\hline
\end{tabular}

Berdasarkan Tabel 3. menunjukkan status Maya Index tinggi sebelum intervensi dan pengumpulan data pertama paling tinggi pada Desa Rejosari sebanyak 33,89\% dibandingkan pada Desa Wonodadi. Status Maya Index sedang sama yaitu 33,33\% sedangkan status Maya Index rendah pada Desa Wonodadi sebanyak $32,92 \%$ dan pada Desa Rejosari sebanyak 32,78\%.
Setelah dilakukan intervensi di Desa Wonodadi dan pengumpulan data kedua di Desa Rejosari status Maya Index tinggi paling tinggi pada Desa Rejosari sebanyak 34,72\% dibandingkan Desa Wonodadi sebanyak 33,3\%. Status Maya Index sedang sama yaitu 33,33\% sedangkan status Maya Index rendah pada Desa Wonodadi sebanyak 33,3\% dan pada Desa Rejosari sebanyak 31,94

Tabel 3

Gambaran Maya Index (MI) Sebelum dan Sesudah Intervensi Pada Kelompok Intervensi (Desa Wonodadi) dan Kelompok Kontrol (Desa Rejosari) Tahun 2019

\begin{tabular}{lcccccccc}
\hline \multirow{2}{*}{$\begin{array}{l}\text { Maya } \\
\text { Index }\end{array}$} & \multicolumn{3}{c}{ Kec. Gadingrejo } & \multicolumn{3}{c}{ Kec. Pringsewu } \\
\cline { 2 - 9 } & \multicolumn{2}{c}{ Sebelum } & \multicolumn{2}{c}{ Sesudah } & \multicolumn{2}{c}{ Sebelum } & \multicolumn{2}{c}{ Sesudah } \\
\hline Rendah & $\mathbf{n}$ & $\mathbf{\%}$ & $\mathbf{n}$ & $\mathbf{\%}$ & $\mathbf{n}$ & $\mathbf{\%}$ & $\mathbf{n}$ & $\mathbf{\%}$ \\
Sedang & 240 & 32.92 & 240 & 33.3 & 236 & 32.78 & 230 & 31.94 \\
Tinggi & 243 & 33.75 & 240 & 33.3 & 240 & 33.33 & 240 & 33.33 \\
\hline Total & 720 & 100 & 720 & 100 & 720 & 100 & 720 & 100 \\
\hline
\end{tabular}

\section{PEMBAHASAN}

Indikator lainnya untuk menilai resiko penularan demam berdarah dengue adalah Maya Index yang menilai tempat penampungan air (TPA) yang ada di suatu wilayah yang terdiri dari Controllable Sites(CS), Disposable Sites (DS), Under Contollable Sites (US) yang hasilnya untuk di Desa Wonodadi setelah dilakukan penanaman sereh wangi jumlah CS postes dibandingkan pretes menurun dan yang mengandung jentik juga turun, sedangkan pada Desa Rejosasi (kelompok kontrol) jumlah CS postes dibandingkan pretes meningkat dan yang mengandung jentik juga turun 
karena pada waktu yang hampir bersamaan ada gerakan penyuluhan demam berdarah dengue dari puskesmas. Hasil penelitian serupa juga didapatkan 835 kontainer, 813 diantaranya kontainer yang dapat dikendalikan, $12,92 \%$ diantaranya ditemukan jentik Ae. Aegypti (Prasetyowati \& Ginanjar, 2017). Terdapat 1215 tempat penampungan air yang diperiksa dengan jenis kontainer controllable sites (CS) yang positif jentik pada kasus paling banyak, yakni bak mandi $(29,27 \%)$, dispenser $(18,29 \%)$, wadah tirta $(18,29 \%)$, sumur $(10,98 \%)$, ember $(6,10 \%)$, gentong $(6,10 \%)$, tempat minum burung $(3,66 \%)$, pot bunga $(2,44 \%)$ (Purnama \& Baskoro, 2012a) . Controllable sites (CS) adalah kontainer yang dapat dikendalikan oleh manusia dengan cara menguras dan menutup untuk mencegah perkembangbiakan nyamuk. Jenis kontainer tersebut mudah untuk di kendalikan sehingga keberadaan jentik Ae. aegypti bisa di turunkan. Jumlah Jentik yang tinggi ditemukan pada bak mandi dikarenakan masyarakat yang terlambat untuk membersihkan bak mandi minimal seminggu sekali. Ember yang digunakan sebagai tempat penampungan air tidak ditutup oleh masyarakat sehingga berpotensi nyamuk Ae. Aegypti meletakkan telurnya dan berkembang biak.

Hasil penelitian serupa ditemukan bahwa jenis Disposable Sites pada kasus yang positif jentik adalah ban bekas $(4,88 \%)$, kaleng bekas $(2,44 \%)$, toples bekas $(2,44 \%)$, dan gelas bekas $(1,22 \%)$ (Purnama \& Baskoro, 2012b). Jumlah TPA yang diperiksa di 23 SD Kecamatan Banjarbaru Utara didapatkan sebanyak 12 (2,4\%) Disposable Sites (Alim, Heriyani, \& Istiana, 2017). Disposable sites (DS) merupakan jenis TPA yang tidak dapat dikontrol karena berupa sampah dan biasanya terdapat di luar rumah serta tidak digunakan lagi dalam rumah tangga. Banyaknya Disposable sites yang ada di lokasi penelitian karena hampir semua barang bekas milik warga dikumpulkan untuk dikelola dan dijual kembali. Tetapi bila terisi air hujan menjadi tempat potensial perkembangbiakan nyamuk jika tidak dibersihkan atau dikubur. Undercontrol sites adalah tempat yang selalu terkontrol, seperti kolam dan akuarium. Tidak ditemukan jentik pada Jenis kontainer UnderControllable sites (US) kolam ikan dan akuarium di Kecamatan Denpasar karena berisi ikan dan tidak terdapat larva Aedes aegypti (Purnama \& Baskoro, 2012a).

Selanjutnya data Breeding Risk Index (BRI), di Desa Wonodadi pada pretes katagori tinggi $50,8 \%$, pada postes mengalami penurunan menjadi $32,5 \%$, di Desa Rejosari pretes katagori tinggi $27,5 \%$, pada postes meningkat menjadi 78,3, sedangkan untuk data Hygiene Risk Index (HRI) Desa Wonodadi kategori tinggi pada pretes 35 $\%$, pada postes menurun menjadi $8,3 \%$ sedangkan di Desa Rejosari pada pretes katagori tinggi $40 \%$ pada postes menurun sedikit menjadi 33,3\%, hal ini menunjukkan bahwa setelah dilakukan intervensi di Desa Wonodadi dan pengumpulan data kedua di Desa Rejosari status Maya Index tinggi paling tinggi pada Desa Rejosari sebanyak 34,72\% dibandingkan Desa Wonodadi sebanyak 33,3\%. Status Maya Index sedang sama yaitu 33,33\% sedangkan status Maya Index rendah pada Desa Wonodadi sebanyak $33,3 \%$ dan pada Desa Rejosari sebanyak 31,94\% memiliki peran untuk menurunkan Breeding Risk Index (BRI) dan Hygiene Risk Index (HRI) meskipun pada Desa Rejosari HRI juga ada penurunan hal ini juga disebabkan adanya penyuluhan pencegahan DBD dari puskesmas. Selanjutnya data Maya Index menunjukkan status Maya Index tinggi sebelum intervensi dan pengumpulan data pertama paling tinggi pada Desa Rejosari sebanyak 33,89\% dibandingkan pada Desa Wonodadi. Status Maya Index sedang sama yaitu 33,33\% sedangkan status Maya Index rendah pada Desa Wonodadi sebanyak $32,92 \%$ dan pada Desa Rejosari sebanyak 32,78\%. BRI yang rendah menunjukkan bahwa hanya terdapat sedikit controllable sites dan memiliki risiko rendah untuk perkembangbiakan larva atau sebaliknya (Prasetyowati \& Ginanjar, 2017; Purnama \& Baskoro, 2012a).

Kategori HRI sebelum dan sesudah intervensi masuk dalam kategori rendah di Desa Wonodadi 
sebanyak (52,5\% dan $80 \%)$ sedangkan di Desa Rejosari masuk dalam kategori tinggi $(40 \%$ dan $33,3 \%)$. HRI yang tinggi menunjukan bahwa terdapat Disposable Sites yang banyak, sehingga rumah tersebut termasuk kategori kotor atau sebaliknya(Prasetyowati \& Ginanjar, 2017; Purnama \& Baskoro, 2012a).

Setelah dilakukan intervensi di Desa Wonodadi dan pengumpulan data kedua di Desa Rejosari status Maya Index tinggi paling tinggi pada Desa Rejosari sebanyak 34,72\% dibandingkan Desa Wonodadi sebanyak 33,3\%. Status Maya Index sedang sama yaitu 33,33\% sedangkan status Maya Index rendah pada Desa Wonodadi sebanyak 33,3\% dan pada Desa Rejosari sebanyak 31,94\%. Maya index (MI) digunakan sebagai upaya pengendalian DBD di suatu daerah karena dapat diketahui tingkat resiko dan tempat perkembangbiakan nyamuk didasarkan pada kebersihan area dan ketersediaan tempat-tempat yang berpotensi sebagai tempat perkembangbiakan nyamuk (Alim et al., 2017; Gama \& Pratiwi, 2017). Hasil ini sejalan dengan hasil (Prasetyowati \& Ginanjar, 2017) bahwa indikator maya index masuk dalam kategori sedang $(70,23 \%)$. Maya index juga digunakan untuk mengidentifikasi sebuah lingkungan beresko tinggi sebagai tempat perkembangbiakan nyamuk Aedes aegypti atau tidak. Hal tersebut telah sesuai bahwa untuk Desa Wonodadi yang katagori tinggi adalah Bretau Risk Index (BRI) maka intervensi dengan penanaman sereh wangi bisa menurunkan pertumbuhan larva nyamuk, sedangkan untuk Desa Rejosari yang katagori tinggi adalah Hygiene Risk Index (HRI) dengan gerakan kebersihan lingkungan yang digerakkan oleh puskesmas bisa mengurangi yang Disposable Sites sehingga pada pemeriksaan kedua (HRI) turun.

\section{KESIMPULAN}

Penanaman tanaman sereh wangi berpengaruh secara statistik terhadap indikator entomolog yaitu peningkatan angka Maya Index baik untuk perbaikan katagori Bretau Risk Index (BRI) maupun Hygiene Risk Index (HRI).

\section{SARAN}

Peningkatan kegiatan PSN diperlukan untuk menekan angka kasus DBD dan perlu adanya sebuah kebijakan daerah yaitu penanaman sereh untuk mengurangi resiko tempat perkembangbiakan nyamuk Aedes aegypti.

\section{DAFTAR PUSTAKA}

Alim, L., Heriyani, F., \& Istiana. (2017). Tingkat Kepadatan Jentik Nyamuk Aedes aegypti pada Tempat Penampungan Air Controllable Sites dan Disposable Sites di Sekolah Dasar Kecamatan Banjarbaru Utara. Berkala Kedokteran, 13(1), 7-14.

Bhatt, S., Gething, P. W., Brady, O. J., Messina, J. P., Farlow, A. W., Moyes, C. L., ... Sankoh, O. (2013). The global distribution and burden of dengue. Nature, 496(7446), 504-507.

Bota, R., Ahmed, M., Jamali, M. S., \& Aziz, A. (2014). Knowledge, attitude and perception regarding dengue fever among university students of interior Sindh. Journal of Infection and Public Health, 7(3), 218-223. https://doi.org/https://doi.org/10 .1016/j.jiph.2013.11.004

Budiman, A. (2016). Hubungan Keberadaan Jentik Nyamuk dan Perilaku Pemberantasan Sarang Nyamuk Demam Berdarah Dengue (PSN-DBD) Masyarakat di Daerah Endemis dan Non Endemis Kecamatan Nanggulan Kabupaten Kulon Progo. Indonesian Journal of Public Health, 11(1), 28-39. Retrieved from

https://www.neliti.com/publicatio ns/162941/hubungan-

keberadaan-jentik-nyamuk-danperilaku-pemberantasan-sarangnyamuk-demam

CDC. (2014). Epidemiology | Dengue | CDC. CDC National Center for Emerging and Zoonotic Infectious Diseases, Division of VectorBorne Diseases. Retrieved from https://www.cdc.gov/dengue/epid emiology/index.html 
Dinkes Kabupaten Pringsewu. (2016). Profil Kesehatan Kabupaten Pringsewu. Kabupaten Pringsewu.

Dinkes Provinsi Lampung. (2016). Profil Kesehatan Provinsi Lampung Tahun 2016. Bandar Lampung.

Dom, N. C., Ahmad, A. H., Ishak, A. R., \& Ismail, R. (2013). Assessing the Risk of Dengue Fever based on the Epidemiological, Environmental and Entomological Variables. Procedia - Social and Behavioral Sciences, 105, 183194.

https://doi.org/10.1016/j.sbspro. 2013.11.019

Gama, Z. P., \& Pratiwi, J. R. (2017). Species Composition of Mosquito and Public Perception about Dengue Vector of Hemorrhagic Fever in Bareng Tenes Malang (Internatio, Vol. 050009). American Institute of Physics. https://doi.org/https://doi.org/10 $.1063 / 1.5012733$

Ho, T. S., Huang, M. C., Wang, S. M., Hsu, H. C., \& Liu, C. C. (2013). Knowledge, attitude, and practice of dengue disease among healthcare professionals in southern Taiwan. Journal of the Formosan Medical Association, 112(1), 18-23. https://doi.org/10.1016/j.jfma.20 12.11.004

Ibrahim, N. K. R., Al-Bar, A., Kordey, M., \& Al-Fakeeh, A. (2009). Knowledge, attitudes, and practices relating to Dengue fever among females in Jeddah high schools. Journal of Infection and Public Health, 2(1), 30-40. https://doi.org/10.1016/j.jiph.20 09.01 .004

Istiqomah, I., BM, S., \& Husodo, B. T. (2017). Faktor-Faktor Yang Berhubungan Dengan Upaya Pencegahan Demam Berdarah Dengue (DBD) Pada Ibu Rumah Tangga di Kelurahan Kramas Kota Semarang. Jurnal Kesehatan Masyarakat (e-Journal), 5(1), 510-518. Retrieved from https://ejournal3.undip.ac.id/inde x.php/jkm/article/view/15831

Kajeguka, D. C., Msonga, M., Schiøler, K. L., Meyrowitsch, D. W.,
Syrianou, P., Tenu, F., ... Kavishe, R. A. (2017). Individual and environmental risk factors for dengue and chikungunya seropositivity in North-Eastern Tanzania. Infection, Disease \& Health, 22(2), 65-76. https://doi.org/https://doi.org/10 $.1016 /$ j.idh.2017.04.005

Kamal, N. N., \& Dharmadi, M. (2017). Pengaruh partisipasi masyarakat dalam pencegahan Demam Berdarah Dengue ( DBD ) terhadap peningkatan kejadian DBD di Wilayah kerja Puskesmas Tegallalang I , Bali. Intisari Sains Medis 2017, 8(1), 77-81. https://doi.org/10.15562/ism.v8i 1.115

Kemenkes. (2016). Profil Kesehatan Indonesia 2015. Kesehatan. Jakarta.

https://doi.org/10.1111/evo.1299 0

Kemenkes. (2017). Data dan Informasi Profil Kesehatan Indonesia 2016. Kementerian Kesehatan RI. Jakarta. Retrieved from http://www.depkes.go.id/resourc es/download/pusdatin/lain-

lain/Data dan Informasi Kesehatan Profil Kesehatan Indonesia 2016 - smaller size web.pdf

Leta, S., Beyene, T. J., De Clercq, E. M., Amenu, K., Kraemer, M. U. G., \& Revie, C. W. (2018). Global risk mapping for major diseases transmitted by Aedes aegypti and Aedes albopictus. International Journal of Infectious Diseases, 67, 25-35. https://doi.org/10.1016/j.ijid.201 7.11 .026

Pang, J., Hsu, J. P., Yeo, T. W., Leo, Y. S., \& Lye, D. C. (2017). Diabetes, cardiac disorders and asthma as risk factors for severe organ involvement among adult dengue patients: A matched case-control study. Scientific Reports, 7(July 2016), 1-11. https://doi.org/10.1038/srep3987 2

Prasetyowati, H., \& Ginanjar, A. (2017). Maya indeks dan kepadatan larva Aedes aegypti di daerah endemis 
DBD Jakarta Timur. Jurnal Vektora, 9(1), 43-49.

Purnama, S. G., \& Baskoro, T. (2012a). Maya Index and Density of Larva Aedes aegypti Dengue Infection. Makara Kesehatan, 16(2), 57-64. Retrieved from http://journal.ui.ac.id/index.php/ health/article/viewFile/1630/1360

Purnama, S. G., \& Baskoro, T. (2012b). Maya Index dan Kepadatan Larva Aedes aegypti. Makara Kesehatan, 16(2), 57-64.

Rulen, B. N., Siregar, S. H., \& Nazriati, E. (2017). Faktor-faktor Yang Mempengaruhi Keberadaan Jentik Aedes aegypti Terhadap Kejadian Demam Berdarah dengue (DBD) di Kecamatan Payung Sekaki Kota Pekanbaru. Dinamika Lingkungan,
4(1), 59-64. Retrieved from https://ejournal.unri.ac.id/index.p hp/DL/article/view/4072

Sayavong, C., Chompikul, J., Wongsawass, S., \& Rattanapan, C. (2015). Knowledge, attitudes and preventive behaviors related to dengue vector breeding control measures among adults in communities of Vientiane, capital of the Lao PDR. Journal of Infection and Public Health, 8(5), 466-473.

https://doi.org/https://doi.org/10 .1016/j.jiph.2015.03.005

WHO. (2016). WHO | Dengue and severe dengue. WHO. World Health Organization.

https://doi.org/10.1111/1469-

0691.12442 